\title{
PENGEMBANGAN MODEL EVALUASI KULTUR SMA
}

\author{
Siswanto \\ Dinas Pendidikan Kabupaten Klaten \\ Jl. Pemuda Selatan 151, Klaten 57424 \\ raysan.octa@yahoo.com
}

\begin{abstract}
Abstrak
Penelitian ini bertujuan untuk 1) mengindentifikasi, 2) mengembangkan model evaluasi, dan 3) mengetahui kelayakan model evaluasi kultur SMA yang dikembangkan. Penelitian ini merupakan penelitian dan pengembangan. Langkah-langkah penelitian dan pengembangan menggunakan acuan pokok dari Plomp, sedangkan penentuan jumlah subjek uji coba menggunakan acuan dari Borg \& Gall. Hasil penelitian menunjukkan bahwa 1) keadaan kultur akademik yang berkembang di SMA saat ini terdiri atas enam aspek budaya, yaitu berprestasi dan berkompetisi, disiplin dan efisien, jujur dan terbuka, gemar membaca, teguran dan penghargaan, serta kerja sama dan kebersamaan; 2) keadaan kultur sosial yang berkembang di SMA saat ini terdiri atas sembilan aspek budaya, yaitu jujur dan terbuka, teguran dan penghargaan, kerjasama dan kebersamaan, saling menghormati, bersih, disiplin dan efisien, bersahabat/komunikatif, saling percaya, dan semangat kebangsaan; 3) hasil confirmatory factor analysis ( $\mathrm{CF} A$ ) menunjukkan bahwa model evaluasi kultur akademik dengan responden siswa dan guru sesuai dengan data lapangan dan model evaluasi kultur SMA yang dikembangkan layak digunakan.
\end{abstract}

Kata kunci: pengembangan model, evaluasi, kultur sekolah 


\title{
DEVELOPING A MODEL OF AN EVALUATION OF THE SCHOOL CULTURE IN SENIOR HIGH SCHOOLS
}

\author{
Siswanto \\ Dinas Pendidikan Kabupaten Klaten \\ Jl. Pemuda Selatan 151, Klaten 57424 \\ Raysan.octa@yahoo.com
}

\begin{abstract}
This study aims to: 1) identify the condition of the school culture in senior high schools (SHSs) at this moment; 2) develop a model of an evaluation of the school culture in SHSs; and 3) know the feasability of the developed model of the evaluation of the school culture in SHSs. This research was a research and development. This steps of the research and development were those proposed by Plomp, while the number of the try out subjects was established using Borg \& Gall. The conclusions of the study are as follows 1) the condition of academic culture which is developing in SHSs consists of six cultural aspects, namely achievement and competition, discipline and efficiency, honesty and openness, reading habit, reward and punishment, and cooperation and togetherness; 2) the condition of social culture which is developing in SHSs consists of nine cultural aspects, namely honesty and openness, reward and punishment, cooperation and togetherness, mutual respect, cleanness, discipline and efficiency, friendliness/communicativeness, mutual trust, and nationalism spirit; 3) the result of the CFA shows that the evaluation model for the academic culture for the students is relevant to the field. Teacher respondance shows that value of $K M O$ is 0,655 ; 4) the result of the social culture for students is relevant to the field. Teacher respondance shows that value of $K M O$ is 0,682 ; 5) the effectiveness of the model of the evaluation of the school culture is judged as a good evaluation model.
\end{abstract}

Keywords: model development, evaluation, school culture 


\section{Pendahuluan}

Telah banyak upaya yang dilakukan untuk meningkatkan kualitas sekolah, namun hasilnya belum memuaskan. Salah satu sebabnya yaitu upaya peningkatan kualitas berada di luar sekolah, pendekatan sentralistik terbukti tak memberikan jaminan pada akselerasi kualitas sekolah. Oleh karena itu, dinamo peningkatan kualitas harus diletakkan kembali ke tempat semestinya, yakni di sekolah. Sekolah sebagai sistem memiliki tiga aspek, yang erat kaitannya dengan kualitas sekolah, yang terdiri dari proses belajar mengajar, kepemimpinan dan manajemen sekolah serta kultur sekolah. Program aksi untuk peningkatan mutu sekolah secara konvensional senantiasa bertumpu pada peningkatan kualitas proses belajar mengajar, sedikit menyentuh aspek kepemimpinan dan manajemen serta kurang menyentuh aspek kultur sekolah.

Perbaikan mutu SMA di Indonesia telah lama dicanangkan oleh Direktorat Pembinaan SMA. Untuk itu diperlukan langkah-langkah dan tindakan nyata dalam meningkatkan kualitas SMA. Adapun langkahlangkah yang perlu dilakukan, Depdiknas (2004:1) menyebutkan ada dua strategi utama dalam memperbaiki dan mengembangkan kualitas sekolah, yaitu (1) fokus terhadap strategi struktural dan (2) fokus terhadap strategi kultural dengan tekanan pada perubahan perilaku. Strategi struktural telah banyak dilakukan oleh Depdiknas, seperti berbagai pengaturan, rekayasa sistem penyampaian informasi yang relevan dengan tuntutan, pergantian kurikulum, dan berbagai pelatihan. Berdasarkan pengalaman yang cukup panjang, cara ini kurang efektif, terutama berhadapan dengan kebutuhan kerja jangka panjang yang dituntut untuk peningkatan kualitas SMA. Perbaikan mutu sekolah memerlukan konsep yang jelas, dukungan yang nyata, dan komitmen yang tinggi dari pihak pemerintah, sekolah, dan masyarakat.

Penerapan strategi struktural telah dilakukan di lingkungan SMA baik sekolah swasta maupun negeri, namun hasilnya belum mencapai seperti yang diharapkan. Berbagai program aksi, seperti penataran manajemen sekolah, pelatihan kepala sekolah, pelatihan para guru, penambahan fasilitas belajar telah dilakukan, namun hasilnya tidak banyak membawa perubahan. Berdasarkan pengalaman yang cukup panjang cara ini kurang efektif, 
karena tidak terjadi peningkatan kualitas yang berkelanjutan. Berbagai pengalaman dan hasil penelitian di dunia bisnis dan pendidikan memberikan tanda bahwa kultur unit-unit pelaksana kegiatan menjadi faktor penentu dalam meningkatkan kualitas.

Berdasarkan pengalaman yang terkait dengan strategi kultural dari beberapa pendapat pakar pendidikan, hasil penelitian para pendidik dapat disimpulkan bahwa kultur sekolah berpengaruh besar terhadap perilaku belajar para siswa di sekolah. Hal ini dibuktikan oleh beberapa hasil penelitian, seperti Stolp (1995) tentang kepemimpinan kultur sekolah. Hasil penelitian tersebut, antara lain menunjukkan bahwa kultur sekolah berkorelasi dengan peningkatan motivasi dan prestasi belajar serta kepuasan kerja dan produktivitas guru. Penelitian yang dilakukan oleh Wagner \& Pellan (2002) dalam Center for Improving School Culture (CISC), bahwa pendidik dan peneliti mencoba menemukan mata rantai yang hilang dalam bidang perbaikan mutu sekolah. Hal tersebut lebih banyak terkait dengan kultur sekolah daripada proyek penataran kurikulum.

Ada beberapa pendapat tentang pengertian kultur, seperti yang dikemukakan oleh Savage \& Armstrong (1996:104)" culture is defined as the constellation of values, beliefs and institutions unique to given group of people". Hal ini berarti, bahwa kultur adalah rangkaian nilai, kepercayaan, dan adat yang unik yang dimiliki oleh sekelompok masyarakat. Schein (1997:103) mendefinisikan kultur sebagai "Suatu pola asumsi dasar hidup yang diyakini bersama yaitu diciptakan, diketemukan, atau dikembangkan oleh sekelompok masyarakat dan dapat digunakan mengatasi persoalan hidup mereka. Oleh karenanya, diajarkan dan diturunkan generasi ke generasi sebagai pegangan perilaku, berpikir, dan rasa kebersamaan di antara mereka".

Depdiknas (2004:1) menyatakan bahwa setiap sekolah mempunyai kultur yang harus dipahami dan dilibatkan agar perubahan yang terjadi bisa berlangsung terus menerus tidak sekedar di permukaan. Kultur sekolah akan menjelaskan bagaimana sekolah berfungsi dan mekanisme internal yang terjadi. Para siswa masuk ke sekolah dengan bekal kultur yang dimiliki, sebagian bersifat positif, yaitu yang mendukung peningkatan kualitas pembelajaran. Namun ada yang negatif, yaitu yang menghambat usaha 
peningkatan kualitas pembelajaran. Sekolah harus berusaha memperkuat kultur yang positif dan menghilangkan kultur yang negatif.

Untuk menciptakan kultur yang kuat dan positif bukan hal yang mudah karena akan banyak hambatan yang dihadapi. Berdasarkan hasil penelitian Gaziel (2005) dengan judul Impact of School Culture on Effectiveness of Secondary School with Disadvantaged Students yang dilakukan di Israel pada sekolah-sekolah menengah pertama, disebutkan bahwa sekolah-sekolah berbeda tentang persepsinya tentang kultur sehingga didapat dimensi kultur yang berbeda pula. Ternyata ini berkorelasi positif dengan kemampuan akademik siswa, partisipasi siswa dalam kegiatan sekolah, teamwork, adaptasi terhadap permintaan masyarakat terhadap sekolah, kerapiannya (orderliness), dan perkembangan sekolah yang berkesinambungan (continuous school improvement).

Untuk mengembangkan kultur sekolah dalam rangka membangun iklim akademik sekolah diperlukan langkah-langkah konkret, seperti memotret kultur sekolah dengan mengamati artefak dan mengamati kegiatan sekolah serta mengamati interaksi antarwarga sekolah, kemudian dianalisis untuk menghasikan klasifikasi kultur positif, netral, atau negatif. Untuk pemotretan tersebut harus digunakan model evaluasi kultur sekolah, yang terdiri dari asesmen artefak, asesmen nilai dan keyakinan, serta asesmen asumsi.

Untuk memiliki model evaluasi kultur sekolah guna melaksanakan pemotretan dalam pengembangan kultur sekolah seperti yang telah diuraikan di atas, dalam penelitian ini dikembangkan model evaluasi kultur SMA dengan mengembangkan kultur akademik dan kultur sosial sesuai dengan karakteristik sekolah dan kebijakan pemerintah pendidikan yang berlaku saat ini. Penelitian ini bertujuan untuk 1) mengindentifikasi, 2) mengembangkan model evaluasi, dan 3) mengetahui kelayakan model evaluasi kultur SMA yang dikembangkan. Penelitian ini merupakan penelitiandan pengembangan. 


\section{Metode Penelitian}

Penelitian ini menggunakan model penelitian dan pengembangan (Research \& Development) yang bertujuan menghasilkan produk berupa model evaluasi kultur SMA. Berdasarkan kajian teoretik model-model penelitian dan pengembangan, dalam penelitian ini model Plomp dikombinasikan dengan model Borg \& Gall (1983). Pengertian kombinasi dalam hal ini adalah langkah-langkah penelitian dan pengembangan menggunakan acuan pokok dari Plomp, sedangkan penentuan jumlah subjek uji coba menggunakan acuan dari Borg \& Gall (1983), yaitu jumlah subjek uji coba dari yang pertama, kedua, dan ketiga semakin meningkat/ bertahap (multistage). Pengertian modifikasi dalam hal ini bahwa implementasi model Plomp dalam penelitian ini sudah dikombinasikan dengan model Borg \& Gall. Prosedur penelitian pengembangan menurut model Plomp melalui lima tahap dan dalam penelitian ini dimodifikasi menjadi empat tahap, yaitu studi pendahuluan, pengembangan, uji lapangan, dan diseminasi/ implementasi.

Model evaluasi yang digunakan adalah model CIPP (Context, Input, Process, and Product) dikembangkan oleh Stufflebeam pada tahun 1965. Prosedur pengembangan model evaluasi kultur sekolah menempuh langkah-langkah (1) penyusunan desain dan perangkat model evaluasi, (2) validasi pakar (expert judgement), (3) uji coba, (4) analisis data, dan (5) diseminasi/implementasi.

Kegiatan uji coba ini dimaksudkan untuk memperoleh data secara lengkap yang dapat digunakan sebagai bahan revisi produk yang dihasilkan. Aspek yang divalidasi dalam tahap uji model evaluasi ini meliputi model evaluasi, panduan model evaluasi, validitas dan reliabilitas instrumen model evaluasi.

Waktu penelitian ini dilaksanakan mulai April sampai dengan bulan Juli 2012 dan lokasi penelitian dilakukan di empat kabupaten, yaitu Kabupaten Klaten, Kabupaten Bantul, Kabupaten Sleman, dan Kabupaten Gunungkidul. Dari empat kabupaten telah diambil lima SMA, yakni SMA Negeri 2 Klaten, SMA Negeri 1 Ngaglik Sleman, SMA Negeri 3 Bantul, 
SMA Negeri 2 Wonosari, dan SMA Negeri 2 Playen Wonosari Gunungkidul.

Jenis data yang diperoleh dalam penelitian ini merupakan data kuantitatif dan kualitatif. Instrumen pengumpulan data dilakukan melalui teknik Delphi. Model hipotetis yang akan diuji secara empiris dalam penelitian ini meliputi evaluasi model evaluasi kultur sekolah, yang terdiri dari kultur akademik dan kultur sosial. Adapun standar besarnya nilai indikator dapat dilihat dalam Tabel 1.

Tabel 1. Goodness of Fit Indices

\begin{tabular}{|c|c|c|}
\hline Goodness of fit index & Cut-of Value & Keterangan \\
\hline Chi-Square & Diharapkan kecil & Untuk $n=100-200 ;$ model \\
\hline Significance Probability & $\geq 0,05$ & $\begin{array}{l}\text { baik bilamana Chi-Square } \\
\text { dengan derajat bebasnya tidak } \\
\text { jauh berbeda }\end{array}$ \\
\hline RMSEA & $\leq 0,08$ & Digunakan untuk n besar \\
\hline GFI & $\geq 0,90$ & Mirip $\mathrm{R}^{2}$ dalam regresi \\
\hline
\end{tabular}

Sumber: Solimun. 2002: 80

Pembuktian validitas isi dilakukan dengan menggunakan rational judgement dan untuk validitas konstruk dianalisis menggunakan analisis faktor dengan program SPSS 19 for windows atau Program Lisrel 8.71. Untuk responden siswa dianalisis dengan $C F A$ (Confirmatory Factor Analysis) dan guru dianalisis mengunakan Exploratory Factor Analysis (EFA). Variabel laten yang dibentuk berdasarkan konsep teoretis dengan beberapa indikator/manifest (Ghozali, 2008: 121). Analisis ini digunakan untuk menguji apakah suatu konstruk dapat dijelaskan oleh indikator-indikatornya. Apabila indikator-indikator dapat membentuk konstruk atau variabel, maka ditunjukkan dengan nilai loading factor yang tinggi, diharapkan nilai Kaiser Meyer Olkin (KMO) lebih besar dari 0,5.

Untuk mengetahui validitas instrumen ditentukan muatan faktor. Butir-butir yang terdapat dalam setiap faktor harus memiliki muatan lebih besar 0,3. Sebagaimana pendapat Nurosis (1986:123) yang mensyaratkan 
muatan faktor minimum pada tiap butir adalah 0,3. Estimasi reliabilitas instrumen digunakan formula Alpha dari Cronbach, bila besarnya indeks sama atau lebih besar dari 0,7 maka instrumen itu tergolong baik (Mardapi, 2007:121).

Konversi data kuantitatif ke data kualitatif dengan skala 5 menggunakan aturan yang merupakan modifikasi dari aturan yang dikembangkan oleh Sudiyono (2003: 329), adalah sebagai berikut.

Tabel 2. Konversi Data Kuantitatif ke Data Kualitatif

\begin{tabular}{ccc}
\hline Rumus & Rerata Skor & Klasifikasi \\
\hline $\mathrm{X}>\bar{X}_{i}+1,8 \times \mathrm{sb}_{\mathrm{i}}$ & $>4,2$ & Sangat Baik \\
$\bar{X}_{i}+0,6 \times \mathrm{sb}_{\mathrm{i}}<\mathrm{X} \leq \bar{X}_{i}+1,8 \times \mathrm{sb}_{\mathrm{i}}$ & $>3,4-4,2$ & Baik \\
$\bar{X}_{i}-0,6 \times \mathrm{sb}_{\mathrm{i}}<\mathrm{X} \leq \bar{X}_{i}+0,6 \times \mathrm{sb}_{\mathrm{i}}$ & $>2,6-3,4$ & Cukup \\
$\bar{X}_{i}-1,8 \times \mathrm{sb}_{\mathrm{i}}<\mathrm{X} \leq \bar{X}_{i}-0,6 \times \mathrm{sb}_{\mathrm{i}}$ & $>1,8-2,6$ & Kurang \\
$\mathrm{X} \leq \bar{X}_{i}-1,8 \times \mathrm{sb}_{\mathrm{i}}$ & $\leq 1,8$ & Sangat Kurang \\
\hline
\end{tabular}

Berdasarkan rerata skor dan klasifikasi hasil pengembangan tersebut kemudian diadakan penilaian terhadap model evaluasi, perangkat maupun panduan model sebagai hasil pengembangan dengan standar penilaian sebagai berikut.

Tabel 3. Standar Penilaian

\begin{tabular}{cll}
\hline $\begin{array}{c}\text { Rerata } \\
\text { Skor }\end{array}$ & Klasifikasi & \multicolumn{1}{c}{ Kesimpulan } \\
\hline$>4,2$ & Sangat Baik & Dapat dijadikan contoh \\
$>3,4-4,2$ & Baik & Dapat digunakan tanpa perbaikan \\
$>2,6-3,4$ & Cukup & Dapat digunakan dengan sedikit perbaikan \\
$>1,8-2,6$ & Kurang & Dapat digunakan dengan banyak perbaikan \\
$\leq 1,8$ & Sangat Kurang & Belum dapat digunakan \\
\hline
\end{tabular}




\section{Hasil Penelitian dan Pembahasan}

Untuk mengindentifikasi keadaan kultur SMA, dilakukan dengan berbasis riset, yaitu melalui review para pakar dengan diskusi panel, teknik Delphi, dan Focus Group Disccussion (FGD). Indikator kultur sekolah dikembangkan berdasarkan kajian teoretis, kajian empiris, dan pengalaman praktik di lapangan serta mengkaji buku-buku yang relevan.

Setelah melakukan elaborasi indikator kultur SMA berdasarkan urutan prioritasnya, kemudian review dilakukan oleh berbagai pakar. Hasil keadaan kultur akademik yang berkembang di SMA saat ini terdiri atas enam aspek budaya, yaitu berprestasi dan berkompetisi, disiplin dan efisien, jujur dan terbuka, gemar membaca, teguran dan penghargaan, kerjasama dan kebersamaan. Hasil keadaan kultur sosial yang berkembang di SMA saat ini terdiri atas sembilan aspek budaya, yaitu jujur dan terbuka, teguran dan penghargaan, kerjasama dan kebersamaan, saling menghormati, bersih, disiplin dan efisien, bersahabat/komunikatif, saling percaya, dan semangat kebangsaan.

Uji lapangan yang dilakukan dengan menguji coba keterbacaan instrumen kultur sekolah dan model evaluasi kultur sekolah dalam rangka menguji model evaluasi kultur sekolah adalah sebagai berikut.

Keterbacaan Instrumen Kultur Sekolah

Tabel 4. Rekapitulasi Hasil Uji Coba Keterbacaan Instrumen Kultur Sekolah

\begin{tabular}{cccccccccccc}
\hline Tahap & $\begin{array}{c}\text { Jumlah } \\
\text { Responden }\end{array}$ & \multicolumn{1}{c}{ Rerata Skor Butir } & \multicolumn{1}{c}{$\begin{array}{c}\text { Rerata } \\
\text { Total }\end{array}$} \\
\cline { 3 - 10 } & 21 & 3,76 & 3,57 & 3,76 & 3,71 & 3,52 & 3,81 & 4,19 & 4,19 & 3,91 & 3,825 \\
1 & 77 & 3,55 & 3,58 & 3,65 & 3,90 & 3,78 & 3,97 & 4,08 & 3,92 & 4,03 & 3,827 \\
2 & 179 & 3,83 & 3,89 & 4,00 & 4,04 & 4,06 & 4,00 & 4,08 & 4,04 & 4,12 & 4,007 \\
3 & & & & & & & & & & &
\end{tabular}


Model Evaluasi Kultur Sekolah

Data kualitatif diperoleh dari hasil validasi (penilaian) dari para ahli (expert) dan pemakai model. Data kuantitatif diperoleh melalui hasil analisis kecocokan/kesesuaian antara model hipotetis dengan data empiris yang dianalisis dengan menggunakan Lisrel dan SPSS.

Tabel 5. Rekapitulasi Hasil Uji Coba Penilaian Model Evaluasi

\begin{tabular}{cccccccccc}
\hline Tahap & Jumlah & \multicolumn{1}{c}{ Rerata Skor Butir } & \multirow{2}{*}{$\begin{array}{c}\text { Rerata } \\
\text { Responden }\end{array}$} \\
\cline { 3 - 8 } & & 1 & 2 & 3 & 4 & 5 & 6 & 7 & \\
\hline 1 & 21 & 4,14 & 3,81 & 3,86 & 3,57 & 4,01 & 3,52 & 4,10 & 3,864 \\
2 & 41 & 3,89 & 3,89 & 3,86 & 3,97 & 3,86 & 4,11 & 4,19 & 3,981 \\
3 & 71 & 4,02 & 3,90 & 4,00 & 4,07 & 4,00 & 3,95 & 4,11 & 4,006 \\
\hline
\end{tabular}

Dengan melihat hasil ketiga analisis tersebut, model evaluasi kultur sekolah (ME-KULSEK) SMA menunjukkan bahwa telah memiliki sifat objektivitas, praktikabilitas dan efisiensi atau ekonomis dengan klasifikasi baik.

Instrumen kultur akademik dengan responden guru dianalisis menggunakan SPSS 19,00 for windows dan responden siswa dianalisis menggunakan confirmatory factor analysis program Lisrel.

1. Instrumen Kultur Akademik

a. Responden siswa

Hasil uji coba tahap pertama merupakan uji coba terbatas, terdiri dari 20 orang (para pakar dan pengguna). Hasil validasi dari para ahli (expert) dan pemakai model menghasilkan klasifikasi baik.

Hasil uji coba tahap kedua menunjukkan semua butir menghasilkan nilai-t muatan faktor lebih dari 1,96, kecuali nomor 42 mempunyai nilai 0,19 dan nomor 43 mempunyai nilai 0,34 . 
Jurnal Penelitian dan Evaluasi Pendidikan

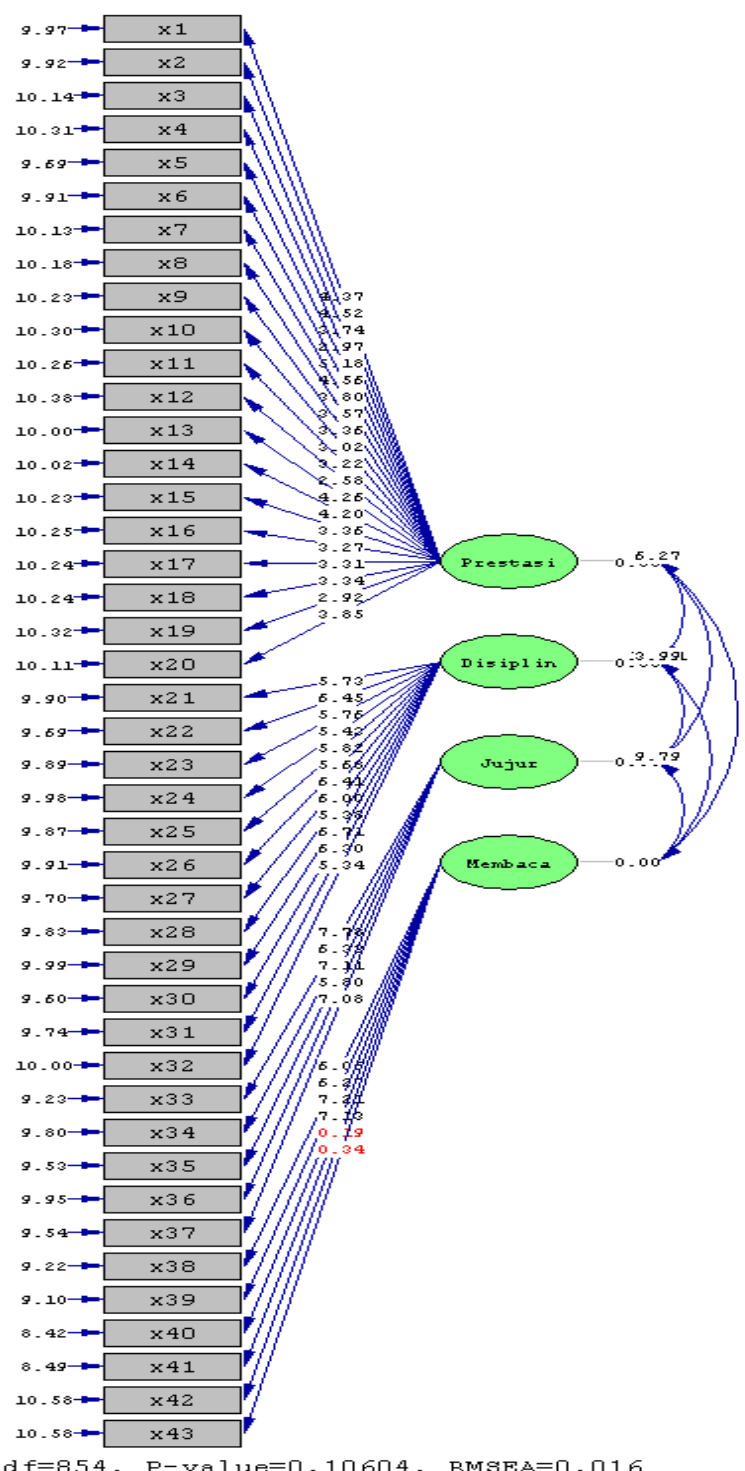

Chi-square $=905.93, d f=854$, P-value $=0.10604$, RMsEA $=0.016$

Gambar 1. Hasil Uji Coba Kedua Model Pengukuran (Konstruk)

Kultur Akademik Responden Siswa

98 - Jurnal Penelitian dan Evaluasi Pendidikan Tahun 17, Nomor 1, 2013 
Hasil analisis tersebut menunjukkan bahwa pada uji coba kedua dengan responden berjumlah 225 dinyatakan dari 43 butir, bahwa butir nomor 1 sampai dengan 41 valid karena memiliki nilai " $t_{\text {hitung }}$ " lebih besar dari " $t_{\text {tabel }}$ ", dan dua butir dinyatakan gugur karena tidak valid, yaitu butir nomor 42 dan 43 karena memiliki " $t_{\text {hitung }}$ " lebih kecil dari " $t_{\text {tabel }}$ " (pada jalur ditandai dengan warna merah). Nilai P-value lebih besar dari 0,05 menunjukkan adanya kesesuaian atau kecocokan antara konsep model pengukuran dengan data lapangan. Nilai $\operatorname{RMSE} A=0,016(<0,80)$ memenuhi syarat sebagai fit model. Nilai $G F I=0,84(>0,90)$ tidak memenuhi syarat sebagai fit model.

Karena adanya dua persyaratan sebagai model yang fit ( $P$-value dan GFI) tidak terpenuhi, instrumen pengukuran kultur sekolah tersebut belum memenui syarat sebagai model pengukuran yang baik. Oleh karena itu, perlu diperbaiki dan diuji coba lagi agar memenuhi syarat sebagai fit model. Untuk indeks reliabilitas instrumen kultur akademik responden siswa mempunyai koefisien Alpha sebesar 0,919 (>0,70).

Pada hasil uji coba ketiga, setelah dianalisis kembali, semua butir menghasilkan nilai-t muatan faktor lebih dari 1,96. Nilai Chi-Square = 823,74, $d f=769, p$-value $=0,08366(>0,05)$, RMSE $A=0,011(<0,080), G F I$ $=0,94(>0,90)$ menunjukkan bahwa model didukung dengan data. Hasil selengkapnya disajikan pada Gambar 2.

Hasil analisis tersebut menunjukkan bahwa pada uji coba ketiga seluruh butir instrumen kultur akademik yang berjumlah 41 butir, dengan responden berjumlah 596 siswa dinyatakan valid, karena memiliki nilai $t_{\text {hitung }}$ lebih besar dari $\mathrm{t}_{\text {tabel }}$ Nilai p-value lebih besar dari 0,05 menunjukkan adanya kesesuaian atau kecocokan antara konsep model pengukuran dengan data lapangan. Nilai RMSE $A=0,011(<0,080)$ memenuhi syarat sebagai fit model. Nilai $G F I=0,94(>0,90)$ memenuhi syarat sebagai fit model. Karena semua persyaratan sebagai model yang fit terpenuhi, instrumen pengukuran kultur akademik tersebut sudah dapat digunakan sebagai model pengukuran yang cocok untuk mengumpulkan data tentang kultur akademik. 


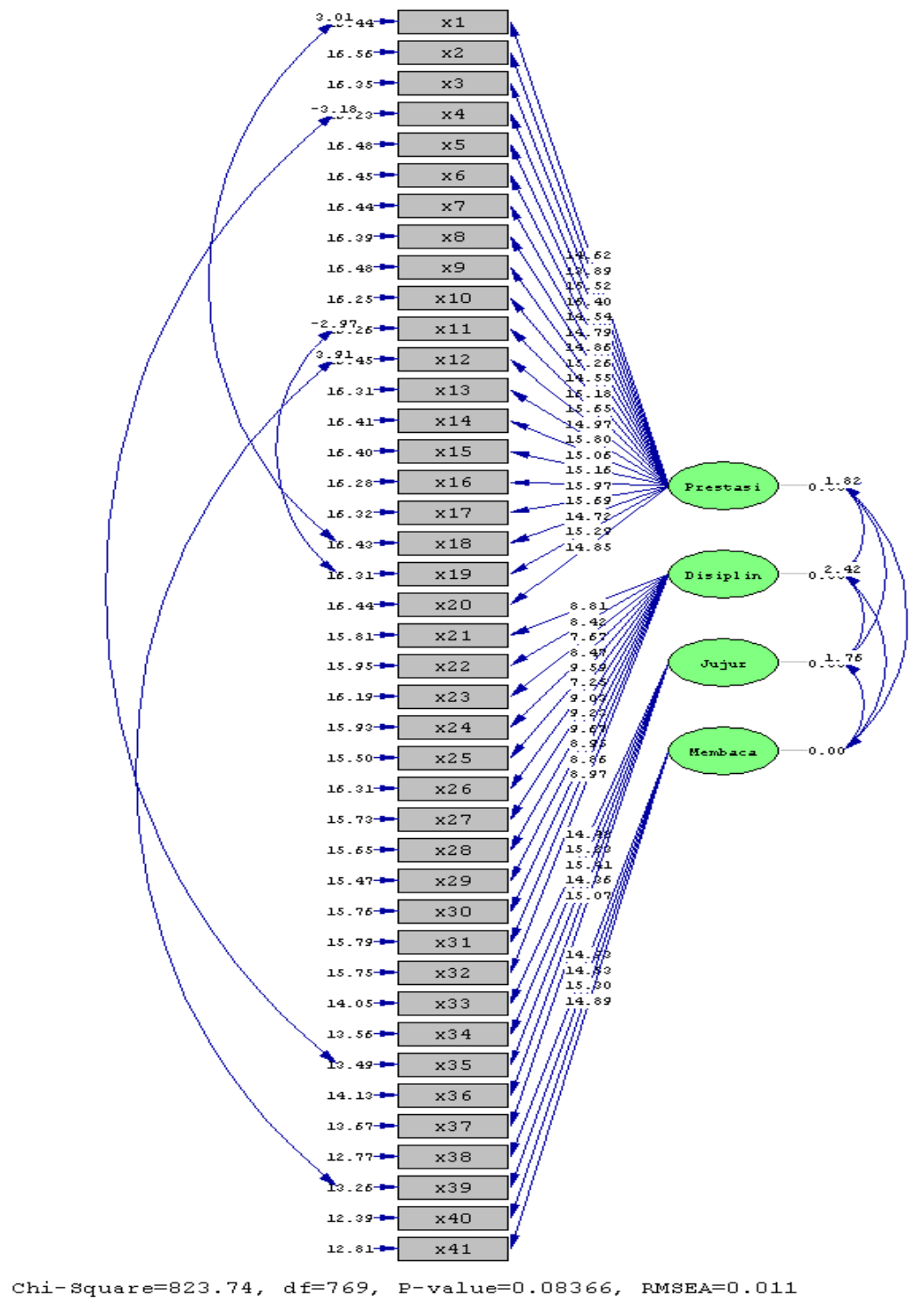

Gambar 2. Hasil Uji Coba Ketiga Model Pengukuran (Konstruk) Kultur AkademikResponden Siswa

100 - Jurnal Penelitian dan Evaluasi Pendidikan Tahun 17, Nomor 1, 2013 
Untuk indeks reliabilitas instrumen kultur akademik responden siswa mempunyai koefisien Alpha sebesar 0,959 (>0,70).

b. Responden guru

Hasil uji coba tahap pertama merupakan uji coba terbatas, terdiri dari 20 orang (para pakar dan pengguna). Hasil validasi dari para ahli (expert) dan pemakai model menghasilkan klasifikasi baik.

Pada hasil uji coba tahap kedua jumlah responden sebanyak 49 orang guru. Hasil analisis data menggunakan SPSS 19.00 for Windows dapat diketahui bahwa semua butir instrumen memenuhi kriteria Kaiser-MeyerOlkin Measure of Sampling Adequacy (KMO) memiliki muatan sebesar 0,596 (lebih besar 0,50) dan mempunyai nilai validitas lebih besar 0,30. Untuk reliabilitas mempunyai koefisien $A \not p h a$ sebesar $0,956(>0,70)$.

Pada hasil uji coba tahap ketiga jumlah responden sebanyak 95 orang guru. Hasil analisis data menggunakan SPSS 19.00 for Windows dapat diketahui bahwa semua butir instrumen memenuhi kriteria Kaiser-MeyerOlkin Measure of Sampling Adequacy (KMO) memiliki muatan sebesar 0,665 (lebih besar 0,50). Untuk reliabilitas mempunyai koefisien Alpha sebesar $0,918(>0,70)$.

Instrumen kultur sosial dengan responden guru dianalisis menggunakan SPSS 19,00 for Windows, sedangkan responden siswa dianalisis menggunakan confirmatory factor analysis program Lisrel. Hasil selengkapnya dari uji coba sebagai berikut.

2. Instrumen Kultur Sosial

a. Responden siswa

Hasil uji coba tahap pertama merupakan uji coba terbatas diperoleh dari hasil validasi dari para ahli (expert) dan pemakai model sebanyak 20 orang. Hasil penilaian tahap pertama menghasilkan rerata skor 3,86 (klasifikasi baik).

Hasil uji coba tahap kedua dilakukan analisis faktor kembali, semua butir memiliki nilai $-\mathrm{t}$ muatan faktor $>1,96$. Nilai Chi-Square $=794,74, d f=$ 750, $P$-value $=0,12504(>0,05), \operatorname{RMSE} A=0,016(<0,080), G F I=0,85(>$ $0,90)$, menunjukkan bahwa model didukung data. 
Hasil analisis tersebut menunjukkan bahwa pada uji coba kedua seluruh butir instrumen kultur sosial dengan responden berjumlah 225 dinyatakan valid karena memiliki nilai $\mathrm{t}_{\text {hitung }}$ lebih besar dari $\mathrm{t}_{\text {tabel }}$ (dalam diagram path ditandai dengan warna hitam). Nilai p-value lebih besar dari 0,05 menunjukkan adanya kesesuaian atau kecocokan antara model pengukuran dengan data lapangan. Nilai RMSE $A=0,016(<0,08)$ memenuhi syarat sebagai fit model. Nilai GFI $=0,85(>0,90)$ belum memenuhi syarat sebagai fit model. Karena adanya dua persyaratan sebagai model yang fit (P-value dan GFI) tidak terpenuhi, maka instrumen pengukuran kultur sosial tersebut belum memenuhi syarat sebagai model pengukuran yang baik. Oleh sebab itu, masih perlu diperbaiki dan diujicobakan lagi. Untuk indeks reliabilitas instrumen kultur sosial responden siswa mempunyai koefisien Alpha sebesar 0,916 (>0,70). Hasil selengkapnya nilai-t masing-masing butir instrumen dapat dilihat pada gambar hasil uji coba kedua model pengukuran (konstruk) kultur sosial responden siswa, sebagai berikut.

Pada hasil uji coba tahap ketiga dinalisis kembali. Semua butir memiliki nilai-t muatan faktor $>1,96$. Nilai Chi-Square $=804,19, d f=743, P_{\text {- }}$ Value $=0,5902(>0,05)$, RMSEA $A=0,012(<0,080)$, GFI $=0,94(>0,90)$ menunjukkan bahwa model didukung data.

Hasil analisis tersebut menunjukkan bahwa pada uji coba ketiga instrumen kultur sosial yang berjumlah 41 butir, dengan responden berjumlah 596 siswa dinyatakan valid karena memiliki nilai " $t_{\text {hitung }}$ " lebih besar dari " $t_{\text {tabel }}$ "(dalam diagram jalur ditandai dengan warna hitam). Nilai P-value lebih besar dari 0,05 menunjukkan adanya kesesuaian atau kecocokan antara model pengukuran dengan data lapangan. Nilai RMSE $A=$ $0,012(<0,080)$ memenuhi syarat sebagai fit model. Nilai GFI $=0,94$ $(>0,90)$ memenuhi syarat sebagai model yang cocok. Karena semua persyaratan sebagai model yang fit terpenuhi, instrumen evaluasi kultur sosial tersebut sudah dapat digunakan sebagai model pengukuran yang cocok untuk mengumpulkan data tentang kultur sosial. Untuk indeks reliabiltas instrumen kultur sosial responden siswa mempunyai koefisien Alpha sebesar $0,94(<0,70)$. 


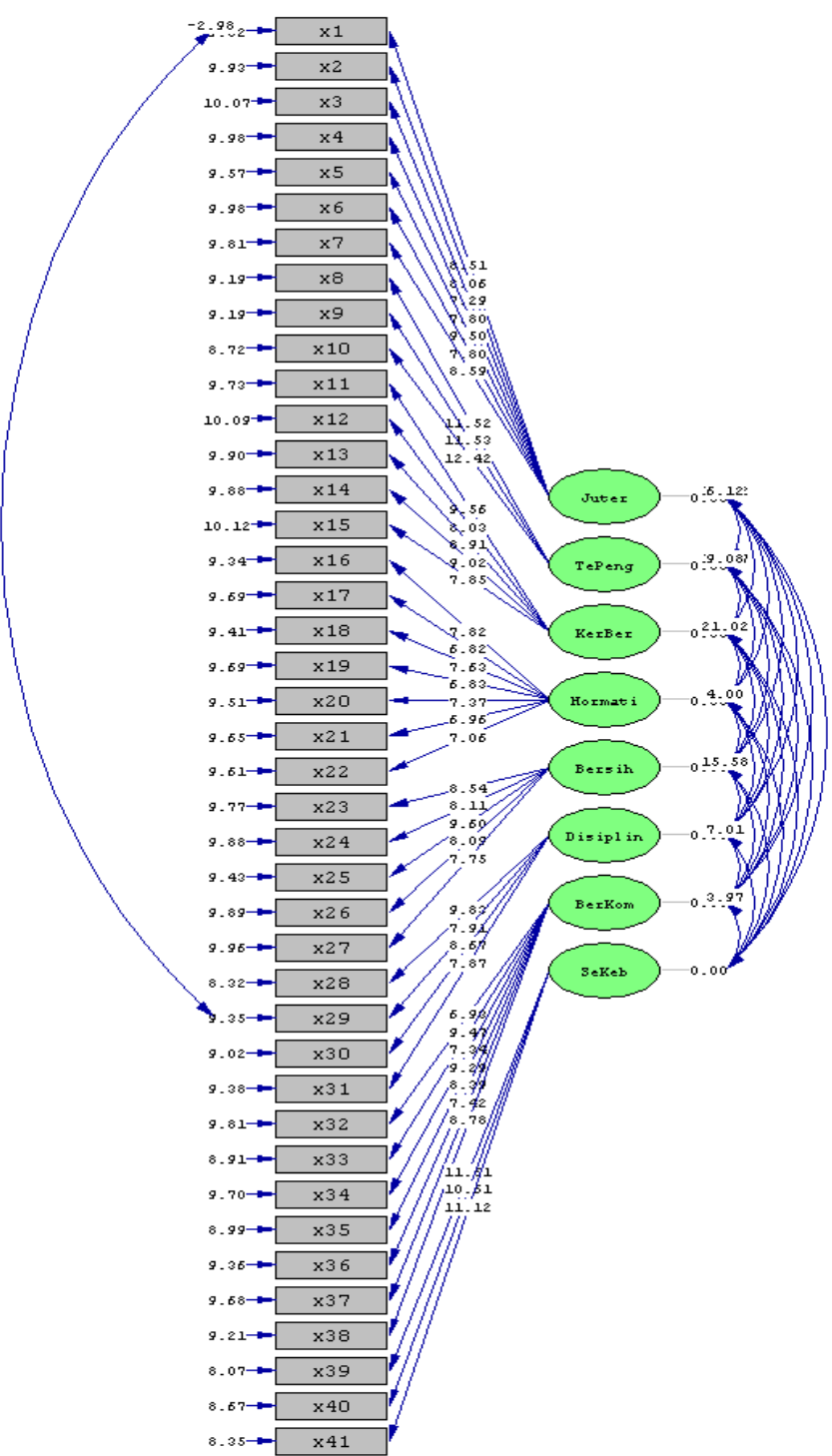

Chi-square $=794.74, d f=750, P-v a l u e=0.12504$, RMSEA $=0.016$

Gambar 3. Hasil Uji Coba Kedua Model Pengukuran (Konstruk) Kultur Sosial Responden Siswa 


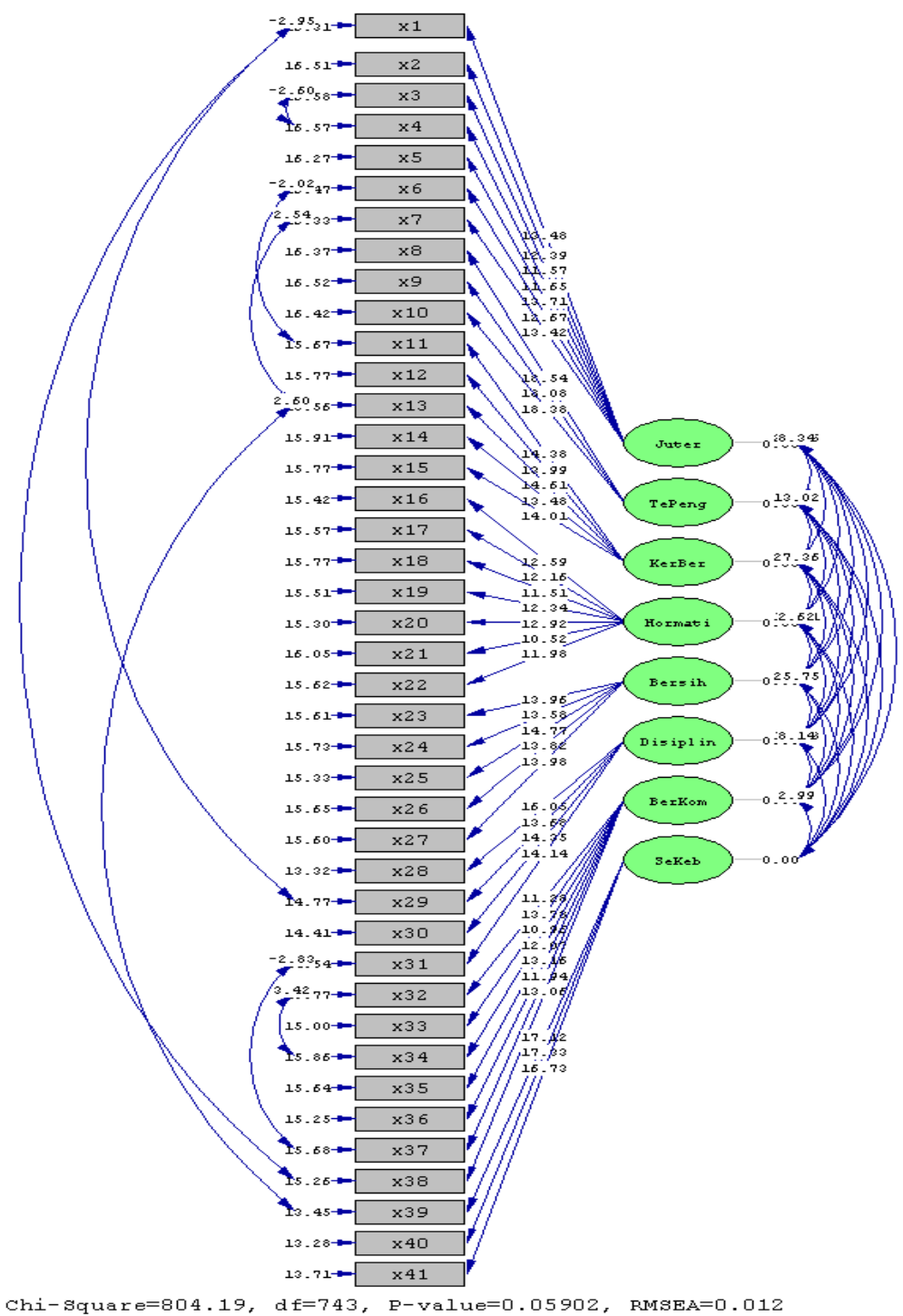

Gambar 4. Hasil Uji Coba Ketiga Model Pengukuran (Konstruk) Kultur Sosial Responden Siswa

104 - Jurnal Penelitian dan Evaluasi Pendidikan Tahun 17, Nomor 1, 2013 
b. Responden guru

Pada hasil uji coba tahap pertama, hasil analisis data kualitatif diperoleh dari hasil validasi dari para ahli (expert) dan pemakai model. Hasil penilaian tahap pertama menghasilkan rerata skor 3,86 (klasifikasi baik).

Hasil uji coba tahap kedua melibatkan jumlah responden sebanyak 49 orang guru. Analisis data instrumen kultur sosial responden guru dapat diketahui bahwa semua butir instrumen penilaian kultur sosial memenuhi kriteria Kaiser-Meyer-Olkin Measure of Sampling Adequacy (KMO) memiliki muatan sebesar 0,524 (lebih besar 0,50). Untuk reliabilitas mempunyai koefisien Alphasebesar 0,919 (>0,70).

Hasil uji coba tahap ketiga melibatkan jumlah responden sebayak 95 orang guru. Analisis data instrumen kultur sosial responden guru dapat diketahui bahwa semua butir instrumen penilaian kultur sosial memenuhi kriteria Kaiser-Meyer-Olkin Measure of Sampling Adequacy memiliki muatan sebesar 0,682 (lebih besar 0,50). Untuk reliabilitas mempunyai koefisien Alpha sebesar 0,935 (>0,70).

Panduan Evaluasi Kultur Sekolah

Tabel 6. Rekapitulasi Hasil Uji Coba Penilaian Panduan Evaluasi

\begin{tabular}{cccccccccc}
\hline Tahap & Jumlah & \multicolumn{9}{c}{ Rerata Skor Butir } & Rerata \\
& Responden & 1 & 2 & 3 & 4 & 5 & 6 & 7 & Total \\
\hline 1 & 20 & 4,14 & 3,81 & 3,86 & 3,57 & 4,14 & 3,52 & 4,10 & 3,878 \\
2 & 41 & 3,69 & 3,47 & 3,92 & 3,97 & 3,866 & 3,92 & 4,18 & 3,884 \\
3 & 71 & 3,81 & 3,85 & 3,97 & 3,96 & 3,91 & 3,91 & 4,07 & 3,924 \\
\hline
\end{tabular}

Model evaluasi kultur sekolah (ME-KULSEK) SMA merupakan salah satu model evaluasi yang cukup sederhana dalam pelaksanaan, tetapi cukup lengkap informasi yang diungkap, sehingga merupakan salah satu alternatif yang dapat digunakan oleh sekolah untuk mengadakan evaluasi terhadap kultur sekolah di SMA. Model evaluasi kultur SMA telah diuji secara kualitatif yang hasilnya menunjukkan bahwa model evaluasi kultur SMA cukup objektif, praktis, dan efisien. 
Hasil analisis kuantitatif dengan analisis Lisrel dan SPSS menunjukkan bahwa model evaluasi kultur sekolah (ME-KULSEK) SMA merupakan model evaluasi yang sesuai atau cocok untuk mengevaluasi program kultur sekolah di SMA, karena model tersebut secara statistik didukung oleh data lapangan, baik dari segi model strukturalnya maupun dari segi model pengukurannya. Model tersebut didukung dengan panduan evaluasi yang cukup singkat tetapi lengkap akan mempermudah implementasi model evaluasi kultur sekolah (ME-KULSEK) di berbagai ragam status dan karakteristik SMA.

\section{Simpulan}

Berdasarkan hasil penelitian dan pembahasan dapat ditarik beberapa simpulan sebagai berikut (1) kultur akademik yang utama berkembang di sekolah saat ini ada enam, yaitu berprestasi dan berkompetisi, disiplin dan efisien, jujur dan terbuka, gemar membaca, teguran dan penghargaan, serta kerjasama dan kebersamaan, kultur sosial yang utama berkembang di sekolah saat ini ada sembilan, yaitu jujur dan terbuka, teguran dan penghargaan, kerjasama dan kebersamaan, saling menghormati, bersih, disiplin dan efisien, bersahabat/komunikatif, saling percaya, dan semangat kebangsaan; (2) hasil uji coba dengan responden siswa dan guru telah memenuhi syarat sebagai model yang cocok (fit model) untuk mengukur kultur akademik; (3) hasil uji coba dengan responden siswa dan guru telah memenuhi syarat sebagai model yang cocok (fit moded) untuk mengukur kultur sosial; (4) efektivitas model evaluasi kultur sekolah termasuk kategori baik, berdasarkan validasi pakar, pemakai/pengguna, dan praktisi.

\section{Daftar Pustaka}

Borg, W.R. \& Gall, M.D. (1983). Educational research: An introduction. New York, NY: Longman.

Depdiknas. (2004). Pedoman pengembangan kultur sekolah. Jakarta: Ditjen Dikdasmen Depdiknas. 
Gaziel, Haim H. (20 Juni 2005). Impact of school, culture on effectiveness of secondary schools with disadvantaged students. Diambil pada tanggal 7 Agustus 2008, dari http://proquest.umi.com/pqdweb?did=8330505 $\&$ sid $=$ Fmt $=4 \&$ lientld $=68516 \& \mathrm{RQT}=309 \& \mathrm{VName}=\mathrm{PQD}$.

Ghozali, Imam \& Fuad. (2005). Structural equation modelling: Teori, konsep dan aplikasi dengan program Lisrel 8,54. Semarang: Badan Penerbit Universitas Diponegoro.

Mardapi, Djemari. (2007). Teknik penyusunan instrumen tes dan nontes. Yogyakarta: Mitra Cendikia Offset.

Nurosis, J.M. (1986). SPSS/PC+for the imbbc/xt/at. Chicago: SPSS.Inc.

Plomp, T. (1997). Development research on/in educational development. Enschende: University of Twente.

Savage, T.V. \& Armstrong, D.G. (1996). Effective teaching in elementary social studies.Third edition. Englewood Cliffs: Merril, Prentice Hall.

Schein, Edgar, H .(1992). Organizational culture and leadership. Second edition. San Fransisco, CA: Jossey Bass A Willey Co.

Solimun. (2002). Structural equation modeling (SEM) lisrel dan amos. Malang: Fakultas MIPA. Universitas Brawijaya.

Stolp, Stephen. (17 September 1995). Leadership for school culture.ERIC Digest Artikel. Diambil pada tanggal 24 Juli 2008, dari http: /www.ericdigest /1995-1/culture.html.

Stufflebeam, D.L. (2003). The CIPP model for evaluation, the article presented at the 2003 annual conference of the Oregon program evaluators network (OPEN) 3 Oktober 2003.Diambil pada tanggal 25 Oktober 2005, dari http://www.wmich.edu/evalctr/cippmodel.

Sudiyono, Anas. (2003).Pengantar evaluasi pendidikan. Jakarta: PT Raja Grafindo Persada.

Wagner, C.R. \& Pellan. (2002). Center for improving school culture (cisc). Diambil pada tanggal 1 Mei 2003, dari http://www.schoolculture.net/ triangle. html. 